\title{
Morpho-functional features of embryonic development of hens at use of covering «Artificial cuticula»
}

\author{
O. Baidevliatova, \\ State Experimental Station of Poultry Industry of NAAS
}

The purpose. To determine morpho-functional features of embryonic development of hens at application of covering «Artificial cuticula». Methods. Study of features of embryonic development of hens was carried out by morphometric researches of the dissected germs from control and test groups. At daily chickens they determined mass and length of body. Results. Features of embryonic development of hens are studied at application of covering «Artificial cuticula». Conclusions. Application of covering "Artificial cuticula» before incubation of eggs promotes acceleration of rate of development of embryos during embryogenesis.

Keywords: «Artificial cuticula», embryonic development, germs of hens.

Introduction. One of the reserves for increase in egg hatchability, output of healthy chickens, improvement of their further productivity and resistance is studying new ways of bird embryonic development stimulation. So urgent is the searching and implementation in incubation technology process various environmentally friendly physical methods, biological and chemical preparations for the treatment of eggs before their setting for incubation in order to stimulate embryonic development, increase egg hatchability, output of healthy birds.

In recent years a number of studies on stimulation of embryonic development by treating poultry eggs with biologically active substances [1,2,5,6,15], ultraviolet radiation [3], monochromatic red light [7] and ozone [13], laser radiation [8] and others for increasing egg hatchability and quantity of conditioned chicks were conducted. Single egg treatment before incubation with «Bactericide» can increase output and safety of chickens [9]. Using «ATM» solution on hatching eggs of ducks had a positive effect on the survival and hatching results of ducklings [10].

However, with such variety of egg treatments search for ecology clean, safe and efficient technologies in poultry farming remains important. Promising in this respect is the technology of «artificial cuticle» "ARTICLE» (ARTIficial cutiCLE) for hatching eggs. «ARTICLE» is a multicomponent protective coverage (produced by biomimetic principle of bird egg natural cuticle) that restores the barrier properties of bio-ceramic structures of the eggshell and its membranes and possesses the biocidal (antibacterial and antiviral) and biostimulating regarding to the developing embryo types of activity [14].

The purpose of this study was to determine the morphological and functional characteristics of chicken embryonic development after the application of the coverage "artificial cuticle."

Materials and methods of the research. The study was conducted on chicken embryos obtained from hen breeds of red Rhode Island, Poltavska glynyasta and Birkivska barvista. Egg samples were taken under state standards. The incubation was performed in laboratory incubators ILB - 0.5 in compliance with standard requirements for the egg incubation process of a certain type of birds [4]. Experiments were performed twice; the data is averaged for the experiments.

To determine the embryonic development 300 eggs were selected from each breed chickens (total of 900 eggs). In control groups (450 eggs) egg treatment was conducted - by formaldehyde vapors, in experimental groups (450 eggs) egg treatment was carried out by the application of the "artificial cuticle" (solution consisting of acid-soluble chitosan dissolved in peracetic acid with the addition of titanium dioxide, water softener, inorganic dye (red pigment), trace elements (magnesium, cobalt, zinc, copper) and water [11].

To study the morphological and functional characteristics of chicken embryos after the application of the coverage of "artificial cuticle" the dissection of the 15 embryos from each group was conducted on the following dates: 72 hours of incubation, 11 and 18 day incubation. Thus, for these studies were selected eggs weighing 5660 grams. Removed embryos were subjected to morphometric studies. In day-old chicks the mass and length were determined. The results were treated by method of variational statistics [12].

Results. Morphometric studies of embryos after 72 hours of incubation (stage of amniotic folds closing) indicate a positive impact of egg treatment in the experimental groups. The embryos of these groups had more than 40 somite pairs, an important characteristic for this age of embryos (Table 1). Compared with the control groups of embryos the ones from research groups had more pairs of somites. Thus in embryos of red Rhode Island the number of somite pairs was higher at $2.19 \mathrm{pc}$. $(P \leq 0,01)$; in Poltavska glynyasta - at $1,41 \mathrm{pc}$. $(P \leq 0,05)$; in Birkivska 
barvista - at 1.83 pc. $(P \leq 0,05)$ respectively. Also, the embryos from experimental groups were more advanced in the development of vascular field than control samples (see table 1).

Table 1. Characteristics of the embryos from the control and experimental groups after 72 hours of egg incubation, $\mathrm{M} \pm \mathrm{m}$.

\begin{tabular}{|l|l|l|l|l|l|l|}
\hline \multirow{2}{*}{ Indexes } & \multicolumn{5}{|l|}{ Chicken breeds } & \multicolumn{2}{l|}{$\begin{array}{l}\text { Poltavska } \\
\text { glynyasta }\end{array}$} & \multicolumn{2}{l|}{ Birkivska barvista } \\
\cline { 2 - 7 } & \multicolumn{2}{|l|}{ red Rhode Island } & $\mathrm{C}$ & $\mathrm{E}$ & $\mathrm{C}$ & $\mathrm{E}$ \\
\cline { 2 - 7 } & $\mathrm{C} 1,2$ & $\mathrm{E}$ & $56,13 \pm 0,86$ & $57,49 \pm 0,8$ & $57,29 \pm 0,97$ & $59,00 \pm 0,84$ \\
\hline $\begin{array}{l}\text { Egg mass before } \\
\text { incubation, g }\end{array}$ & $57,79 \pm 0,63$ & $57,59 \pm 0,91$ & & & & \\
\hline $\begin{array}{l}\text { Egg mass at the } \\
\text { moment of } \\
\text { dissection, g }\end{array}$ & $56,42 \pm 0,63$ & $56,29 \pm 0,86$ & $54,90 \pm 0,85$ & $56,24 \pm 0,77$ & $55,8 \pm 0,97$ & $57,79 \pm 0,83$ \\
\hline $\begin{array}{l}\text { The large diameter of } \\
\text { vascular field, mm }\end{array}$ & $34,38 \pm 0,79$ & $34,75 \pm 0,95$ & $33,70 \pm 0,84$ & $35,00 \pm 1,13$ & $34,29 \pm 0,86$ & $35,53 \pm 0,94$ \\
\hline $\begin{array}{l}\text { The small diameter } \\
\text { of vascular field, mm }\end{array}$ & $28,97 \pm 0,76$ & $30,64 \pm 0,73$ & $29,33 \pm 0,6$ & $30,15 \pm 0,88$ & $29,43 \pm 0,85$ & $30,57 \pm 0,95$ \\
\hline $\begin{array}{l}\text { Number of somite } \\
\text { pairs, pc. }\end{array}$ & $38,17 \pm 0,54$ & $40,36 \pm 0,43^{* *}$ & $38,48 \pm 0,45$ & $39,89 \pm 0,4^{*}$ & $38,57 \pm 0,57$ & $40,40 \pm 0,4^{*}$ \\
\cline { 4 - 7 }
\end{tabular}

Notes. Hereinafter: ${ }^{1}$ - C (control group) - treatment of the eggs by formaldehyde vapors; $E$ (experimental groups) - treatment of the eggs by working solution of acid-soluble chitosan dissolved in peracetic acid with the addition of titanium dioxide, water softener, inorganic dye (red pigment), trace elements (magnesium , cobalt, zinc, copper) and water. ${ }^{2}$ - significant difference between $C$ and $E$ groups $\left({ }^{* * *}-P \leq 0,001^{* *}-P \leq 0,01^{*}-P \leq 0,05\right)$.

The data of embryonic development of 11-day-old embryos (stage of protein sac formation and allantois closing) also indicates the positive impact of preincubation egg treatment by «ARTICLE» on embryogenesis (Table 2). In the experimental groups significantly $(P \leq 0,001)$ increases the mass of embryos - 4,82 $\pm 0,07 \mathrm{~g}$ (red Rhode Island), $4,76 \pm 0,07 \mathrm{~g}$ (Poltavska glynyasta), 4,87 $\pm 0,07 \mathrm{~g}$ (Birkivska barvista) compared to the embryo weight in control groups $4,03 \pm 0,08 \mathrm{~g} ; 4,07 \pm 0,09 \mathrm{~g} ; 4,40 \pm 0,09 \mathrm{~g}$ respectively. There was also the increase in the length of the chicken embryos from experimental groups. Thus, the length of the embryos in the research groups was $48,92 \pm$ 0,35 mm (red Rhode Island), ( $\leq \leq 0,01) ; 49,18 \pm 0,44 \mathrm{~mm}$ (Poltavska glynyasta), $(P \leq 0,05) ; 49,43 \pm 0,39 \mathrm{~mm}$ (Birkivska barvista) $(P \leq 0,05)$, which is $1.92 \mathrm{~mm}, 1.35 \mathrm{~mm}$ and $1.43 \mathrm{~mm}$ respectively more in length compared to control groups of embryos. Thus, in the eggs of experimental groups we observed some decreasing in protein and "new plasma" weights which indicated the intensive use of the main nutrients from food sources during this period.

Table 2. Characteristics of the embryos from the control and experimental groups after 11 days of egg incubation, $\mathrm{M} \pm \mathrm{m}$.

\begin{tabular}{|l|l|l|l|l|l|l|}
\hline \multirow{2}{*}{ Indexes } & \multicolumn{4}{l|}{ Chicken breeds } \\
\cline { 2 - 7 } & \multicolumn{2}{l|}{ red Rhode Island } & \multicolumn{2}{l|}{ Poltavska glynyasta } & \multicolumn{2}{l|}{ Birkivska barvista } \\
\cline { 2 - 7 } & $\mathrm{C}$ & $\mathrm{E}$ & $\mathrm{C}$ & $\mathrm{E}$ & $\mathrm{C}$ & $\mathrm{E}$ \\
\hline $\begin{array}{l}\text { Egg mass before } \\
\text { incubation, g }\end{array}$ & $59,74 \pm 1,07$ & $59,36 \pm 0,74$ & $58,74 \pm 0,92$ & $58,48 \pm 0,74$ & $57,71 \pm 0,92$ & $57,73 \pm 1,14$ \\
\hline $\begin{array}{l}\text { Egg mass at the } \\
\text { moment of dissection, } \\
\mathrm{g}\end{array}$ & $55,46 \pm 0,98$ & $54,97 \pm 0,71$ & $54,43 \pm 0,84$ & $54,51 \pm 0,74$ & $53,47 \pm 0,94$ & $53,64 \pm 1,08$ \\
\hline Embryo length, $\mathrm{mm}$ & $47,00 \pm 0,54$ & $48,92 \pm 0,35^{\star *}$ & $47,83 \pm 0,46$ & $49,18 \pm 0,44^{*}$ & $48,00 \pm 0,44$ & $49,43 \pm 0,39^{*}$ \\
\hline Embryo mass, g & $4,03 \pm 0,08$ & $4,82 \pm 0,07^{* * *}$ & $4,07 \pm 0,09$ & $4,76 \pm 0,07^{* * *}$ & $4,40 \pm 0,09$ & $4,87 \pm 0,07^{* * *}$ \\
\hline Egg white mass, g & $11,20 \pm 0,31$ & $10,90 \pm 0,25$ & $11,17 \pm 0,32$ & $11,09 \pm 0,21$ & $10,21 \pm 0,28$ & $10,05 \pm 0,31$ \\
\hline New plasma mass, g & $7,56 \pm 0,40$ & $6,40 \pm 0,35^{*}$ & $7,58 \pm 0,37$ & $5,79 \pm 0,19^{* * *}$ & $6,89 \pm 0,42$ & $5,61 \pm 0,28^{*}$ \\
\hline
\end{tabular}

The results of the egg dissection on the $18^{\text {th }}$ day of incubation (stage of muscular layer formation around the yolk sac and early involvement of the small intestine to the abdominal cavity of the fetus) indicate that the embryos of experimental groups had the best characteristics of development compared with control (Table 3). The weight and length of the embryos continued to grow. In this period the mass of embryos was $27.57 \mathrm{~g}$ (red Rhode Island), 
$28.74 \mathrm{~g}$ (Poltavska glynyasta), $28.64 \mathrm{~g}$ (Birkivska barvista), which was $2.2 \mathrm{~g}(\mathrm{P} \leq 0,05), 1.8 \mathrm{~g}, 2.1 \mathrm{~g}(\mathrm{P} \leq 0,05)$ respectively more than the mass of the samples from control groups. The length of the embryos was $87,04 \mathrm{~mm}$ (red Rhode Island), $87.22 \mathrm{~mm}$ (Poltavska glynyasta), 86,50mm (Birkivska barvista), which was by $2.32 \mathrm{~mm}(\mathrm{P} \leq 0,05)$ $1.15 \mathrm{~mm}, 1.14 \mathrm{~mm}$ above than the length of embryos from control groups. In embryos from research groups visually observed the following - amnion surrounded fetal body tightly, as in its cavity no amniotic fluid and protein left. The mass of allantoic fluid in experimental groups of embryos significantly reduced (see Table. 3). This indicated the better preparation to the hatch and more intensive use of the substances of yolk sac by the embryos of experimental groups.

Table 3. Characteristics of the embryos from the control and experimental groups after 18 days of egg incubation, $\mathrm{M} \pm \mathrm{m}$.

\begin{tabular}{|l|l|l|l|l|l|l|}
\hline \multirow{2}{*}{ Indexes } & \multicolumn{3}{|l|}{ Chicken breeds } & \multicolumn{2}{l|}{ Poltavska glynyasta } & \multicolumn{2}{l|}{ Birkivska barvista } \\
\cline { 2 - 6 } & red Rhode Island & $\mathrm{E}$ & $\mathrm{E}$ & $\mathrm{C}$ & $\mathrm{E}$ \\
\cline { 2 - 6 } & $\mathrm{C}$ & $59,74 \pm 0,71$ & $59,20 \pm 0,74$ & $60,98 \pm 0,96$ & $59,02 \pm 0,82$ & $60,40 \pm 0,90$ \\
\hline $\begin{array}{l}\text { Egg mass before } \\
\text { incubation, g }\end{array}$ & $60,10 \pm 0,79$ & & & & & \\
\hline $\begin{array}{l}\text { Egg mass at the } \\
\text { moment of } \\
\text { dissection, g }\end{array}$ & $52,55 \pm 0,74$ & $52,56 \pm 0,70$ & $52,24 \pm 0,76$ & $54,19 \pm 0,98$ & $52,04 \pm 0,73$ & $53,15 \pm 0,90$ \\
\hline $\begin{array}{l}\text { Embryo length, } \\
\text { mm }\end{array}$ & $84,72 \pm 1,19$ & $87,04 \pm 0,94^{*}$ & $86,07 \pm 0,8$ & $87,22 \pm 0,65$ & $85,36 \pm 0,86$ & $86,50 \pm 0,83$ \\
\hline Embryo mass, g & $25,37 \pm 0,68$ & $27,57 \pm 0,42^{*}$ & $26,94 \pm 0,29$ & $28,74 \pm 0,48$ & $26,54 \pm 0,37$ & $\begin{array}{l}28,64 \pm \\
0,44^{*}\end{array}$ \\
\hline $\begin{array}{l}\text { Allantoic fluid } \\
\text { mass, g }\end{array}$ & $4,63 \pm 0,37$ & $3,48 \pm 0,31^{*}$ & $3,23 \pm 0,25$ & $2,88 \pm 0,21$ & $3,26 \pm 0,24$ & $\begin{array}{l}2,32 \pm \\
0,25^{* *}\end{array}$ \\
\hline
\end{tabular}

Day-old chicks from the experimental groups had a greater live weight and length than chickens in control groups. The chickens of red Rhode Island breed of the experimental group had live weight at $3.22 \mathrm{~g}(\mathrm{P} \leq 0,01)$ higher than the chickens in the control group. The chickens from the experimental groups of Poltavska glynyasta and Birkivska barvista had higher live weight at 2.40 grams and 2.23 grams $(P \leq 0,05)$, respectively compared to the live mass of the chickens from the control groups. The length of the chickens from research groups was also significantly higher than the one in the control groups - at $3.81 \mathrm{~mm}, 4.58 \mathrm{~mm}(P \leq 0,01)$ in chicken breeds of red Rhode Island and Poltavska glynyasta and $2.35 \mathrm{~mm}(P \leq 0,05)$ in chickens of Birkivska barvista (Table 4).

Table 4. Characteristics of the day-old chicks from the control and experimental groups, M $\pm m$.

\begin{tabular}{|l|l|l|l|l|l|l|}
\hline \multirow{2}{*}{ Indexes } & \multicolumn{4}{|l|}{ Chicken breeds } & \multicolumn{4}{l|}{ Poltavska glynyasta } & \multicolumn{3}{l|}{ Birkivska barvista } \\
\cline { 2 - 7 } & red Rhode Island & $\mathrm{C}$ & $\mathrm{C}$ & $\mathrm{E}$ & $\mathrm{C}$ \\
\cline { 2 - 6 } & $\mathrm{C}$ & $\mathrm{E}$ & $39,02 \pm 0,47$ & $41,42 \pm 0,49^{*}$ & $39,66 \pm 0,4$ & $41,89 \pm 0,47^{*}$ \\
\hline $\begin{array}{l}\text { Chicken } \\
\text { mass, g }\end{array}$ & $39,05 \pm 0,48$ & $42,27 \pm 0,52^{* *}$ & & & & \\
\hline $\begin{array}{l}\text { Chicken } \\
\text { length, } \mathrm{mm}\end{array}$ & $103,88 \pm 2,91$ & $107,69 \pm 2,49^{* *}$ & $99,42 \pm 1,86$ & $104,00 \pm 2,88^{* *}$ & $101,04 \pm 2,11$ & $103,39 \pm 1,6^{*}$ \\
\hline
\end{tabular}

Considering the above data, we can conclude that the protective coverage "artificial cuticle» («ARTICLE») has biostimulating activity in respect of the developing embryos.

\section{Conclusions}

The application of the coverage "artificial cuticle" before setting eggs for incubation accelerates the rate of embryo development during embryogenesis.

\section{Bibliography}

1. Azarnova T.O. Primenenie jekologicheski bezopasnogo preparata ribav dlja stimuljacii jembrional'nogo $\mathrm{i}$ postjembrional'nogo razvitija jaichnyh cypljat: avtoref. dis. na soiskanie nauch. stepeni kand. biol. nauk: 16.00.06/T.O. Azaronova; [MGAVMiB]. - M., 2006. - 20 s. 
2. Brjushinin N.V. Primenenie jekologicheski bezopasnyh preparatov dlja stimuljacii jembrional'nogo i postjembrional'nogo razvitija brojlerov, ih rezistentnosti i produktivnosti: dis. na soiskanie nauch. stepeni kand. vet. nauk: 16.00.03/N.V. Brjushinin; [MGAVMiB]. - M., 2006. - 126 s.

3. Burdashkina V.O. Obluchenie povyshaet vyvodimost'/V.O. Burdashkina //Pticevodstvo. - 2003. - №4. - S. 8.

4. Inkubacija jaic sel'skohozjajstvennoj pticy/M.T. Tagirov, N.V. Shomina, A.B. Artemenko [i dr.]. - Borki, 2009. $-131 \mathrm{~s}$.

5. Kochish I.I. Jekologicheski bezopasnye sposoby stimuljacii rosta i razvitija brojlerov $v$ ontogeneze/l.I. Kochish, M.S. Najdenskij, E.S. Elizarov, O.I. Kochish//M.: FGOU VPO «MGAVMiB im. Skrjabina», ONO PPZ «Konkursnyj», 2007. - $104 \mathrm{~s}$.

6. Kuz'mina C.B. Vlijanie jekologicheski bezopasnogo preparata mitomina na nekotorye pokazateli jembrional'nogo i postjembrional'nogo razvitija perepelov: avtoref. dis. na soiskanie nauch. stepeni kand. biol. nauk: 16.00.06/C.B. Kuz'mina; [MGAVMiB]. - M., 2006. - $18 \mathrm{~s}$.

7. Mel'nichenko O.P. Vpliv monohromatichnogo chervonogo svitla na embrional'nij rozvitok ta vivedennja molodnjaku kurej ta perepeliv zi svizhogo ta prignichenogo inkubacijnogo jajcja/O.P.Mel'nichenko//Efektivne ptahivnictvo. - 2009. - №3 (51). - S. 34.

8. Mel'nikova I.I. Predynkubaciinnoe obluchenie jaic utok krossov H-11 i Medeo gelij-neonovym lazerom i ego vlijanie na postjembrional'noe razvitie utjat-brojlerov/l.I. Mel'nikova//Mezhvuz. sb. nauch. tr. M., 1990. S. 16-21.

9. Nikolaenko V.P. Jeffektivnyj antiseptik baktericid/V.P. Nikolaenko, I.N. Shhedrov//Ptica i pticeprodukty. 2008. - № 1. - S. 39-44.

10. Nikolaenko V.P. Dezinfekcija utinyh jaic preparatom ATM/V.P. Nikolaenko//Pticevodstvo. - 2001. - №3. - S. $42-43$.

11. Pat. na korisnu model' №59917 UA, MPK51 A01K43/00, A01K41/00. Sposib zahistu inkubacijnih jaєc' kurej pokrittjam z hitozanu / O.G. Bordunova, O.G. Astrahanceva, O.M. Bajdevljatova, V.D. Chivanov; zajavnik ta patentovlasnik Sums'kij NAU. - № u 201011919; zajavl. 08.10.2010; opubl. 10.06.2011, Bjul. № 11.

12. Plohinskij N.A. Rukovodstvo po biometrii dlja zootehnikov/N.A. Plohinskij. - M.: Kolos, 1969. $-256 \mathrm{~s}$.

13. Prokopenko A.V. Dezinfekcija inkubatorov UFL i ozonom/A.V. Prokopenko//Pticevodstvo. - 1997. - №3. - S. $11-14$

14. Samohina $€$.A. Biomimetichna tehnologija zahistu inkubacijnih jaєc' kurej z vikoristannjam nano kompozitiv hitozanu i dioksinu titana/E.A. Samohina, O.G. Bordunova, V.D. Chivanov//Tavrijs'kij naukovij visnik. - 2008. №56. - S. 104-115.

15. Shafey, T.M. Eggshell conductance, embryonic growth, hatchability and embryonic mortality of broiler breeder eggs dipped into ascorbic acid solution/T.M Shafey//Brit. Poultry Sci. - 2002. - V. 43. - P. 135-140. 